Banking Sector Reform and Interest Rates in Transition Economies: Bank-Level Evidence from Kyrgyzstan

Martin Brown, Maria Rueda Maurer, Tamara Pak and Nurlanbek Tynaev

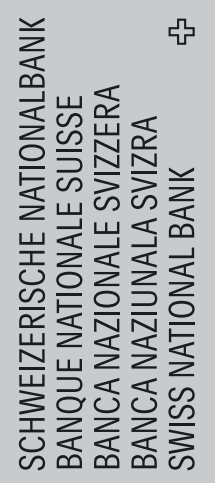


The views expressed in this paper are those of the author(s) and do not necessarily represent those of the Swiss National Bank. Working Papers describe research in progress. Their aim is to elicit comments and to further debate.

ISSN $1660-7716$

๑ 2007 by Swiss National Bank, Börsenstrasse 15, P.0. Box, CH-8022 Zurich 


\title{
Banking Sector Reform and Interest Rates in Transition Economies: Bank-Level Evidence from Kyrgyzstan
}

\author{
Martin Brown ${ }^{+}$, Maria Rueda Maurer*, \\ Tamara Pak**, Nurlanbek Tynaev***
}

This version: February 2007

First version: April 2006

\begin{abstract}
We examine the impact of banking sector reforms on interest rates using bank-level data from Kyrgyzstan for 1998-2005. We find that increased confidence in the banking sector has contributed significantly to lowering interest rate levels, while the impact of lower intermediation costs, credit risk, and capital costs are negligible. Our results further suggest that the liberalization of the Kyrgyz financial sector has reduced both deposit and lending rates. Finally, we find that despite considerable restructuring, the Kyrgyz banking sector has not become more competitive. As a consequence, banks' interest rates have not fully responded to lower market rates following macroeconomic stabilization.
\end{abstract}

Keywords: Transition, Financial Sector Development, Interest Rates

JEL: G21, 016, P34

${ }^{+}$Corresponding author: martin.brown@,snb.ch. * Swiss National Bank ** National Bank of the Kyrgyz Republic *** Ministry of Economy and Finance of the Kyrgyz Republic. We thank our colleagues at the Swiss National Bank and the National Bank of the Kyrgyz Republic, as well as an anonymous referee for helpful comments. The views expressed in this paper do not necessarily reflect those of the Swiss National Bank, the National Bank of the Kyrgyz Republic, or those of the Ministry of Economy and Finance of the Kyrgyz Republic. 


\section{Introduction}

Over the past decade, most countries in Eastern Europe and the former Soviet Union have pursued reforms aimed at increasing the size, stability and efficiency of their financial sectors. Banking supervision has been tightened with the aim of restoring confidence in the banking sector (Berglof and Bolton, 2002). The financial sector has been liberalized with the goal of inducing stronger competition and more efficient intermediation (Bonin and Wachtel, 2003). Moreover, company and bankruptcy laws have been reformed in order to reduce credit risk, by facilitating transparency and contract enforcement (Pistor et al., 2000). In addition to these structural reforms, the stabilization of monetary and fiscal policy has created a macroeconomic environment which is more conducive to financial intermediation. Recent data suggests that the macroeconomic and structural reforms pursued by transition countries have been successful in fostering financial sector development. Between 1998 and 2005 the ratio of private credit to GDP increased from $31 \%$ to $46 \%$ in Central and Eastern Europe, from $18 \%$ to $28 \%$ in Southeast Europe and from $8 \%$ to $19 \%$ in CIS countries. ${ }^{1}$ This substantial deepening of the financial sector in transition countries has been accompanied by a marked reduction in banks' interest rates. Between 1998 and 2005 average nominal lending rates over all countries fell from $32.9 \%$ to $12.9 \%$, while deposit rates dropped from $16.4 \%$ to $5.4 \%$. The intermediation spread of banks (lending rate minus deposit rate) has thus, on average, been more than halved from 16.5 to just $7.5 \%$.

Are these welcome developments in banks' interest rates simply a result of widespread macroeconomic stabilization? Or have they also been fuelled by structural reforms to the banking sector? Since 1998 consumer price inflation in transition countries has fallen, on average from $14.6 \%$ to $5.7 \%$, suggesting that the similar reduction in nominal deposit rates may be purely a result of a more stable monetary policy. However, the more dramatic fall in lending rates, and the subsequent decline in banks' intermediation spreads, suggest that interest rate developments may not be entirely attributed to improved macroeconomic

\footnotetext{
${ }^{1}$ The figures reported in this paragraph are unweighted averages across countries based on IFS statistics. Regional definitions are taken from the 2006 EBRD transition report: Southeast Europe (SEE) includes Albania, Bulgaria, Bosnia \& Herzegovina, Macedonia and Romania. Central Eastern Europe (CEE) includes Croatia, the Czech Republic, Estonia, Hungary, Latvia, Lithuania, Poland, the Slovak Republic, and Slovenia. Commonwealth of Independent States (CIS) includes Armenia, Azerbaijan, Belarus, Georgia, Kazakhstan, Kyrgyzstan, Moldova, Russia, Tajikistan, and Ukraine. We exclude Turkmenistan and Uzbekistan due to lack of data.
} 
stability. Existing research on financial sector development in transition countries suggests that structural reforms to the banking sector have been instrumental in improving the efficiency of financial intermediation. Examining the performance of over 500 banks in 16 transition countries, Fries et al. (2002) find that in countries where banking sector reforms have been pursued more vigorously, banks earn lower interest margins. More recent research by Bonin et al. (2005) also find that financial liberalization has significantly improved bank efficiency in 11 transition countries. This result confirms the findings of Grigorian and Manole (2002) and Fries and Taci (2004) using similar bank-level accounting data.

In this paper we use bank-level interest rate data to examine how banking sector reform has affected financial intermediation in one transition country; Kyrgyzstan. Our data captures the lending and deposit taking activities in local and foreign currency of all Kyrgyz banks on a quarterly basis from 1998 to 2005 . It therefore allows us to examine the relation between banking sector developments and interest rates more precisely than previous studies. First, as we observe the actual interest rates set by banks on new loans and deposits per quarter, we have much more precise information on interest rates than that generated from income statement data in previous studies. Second, as we observe banks' interest rates for both local currency and foreign currency funds, we can compare interest developments which should depend strongly on domestic macroeconomic conditions (local currency lending and deposit rates) from those which should depend less on domestic macroeconomic conditions (foreign currency lending and deposit rates).

Kyrgyzstan is an interesting country in which to study the impact of banking sector reforms on financial sector development. On the one hand, Kyrgyzstan followed a structural reform path which is characteristic for many other transition countries. The banking sector was initially privatized and liberalized at a fast pace, notwithstanding a weak regulatory environment. After initial bank failures the sector was then restructured, and regulation tightened. Finally, in recent years Kyrgyzstan has seen a strong increase in foreign bank control. On the other hand, Kyrgyzstan belongs to the low-income transition countries, for which there is scarce evidence on the determinants of financial sector development. Relying on income-statement data of banks, existing studies necessarily focus on developments in the more advanced European transition countries, for which this data is publicly available. The little evidence available for low-income transition countries suggests that banking sector reform may be less effective in these low-income countries. De Nicolo et al. (2003) examine 
intermediation spreads in CIS- $7^{2}$ countries for the period 1995-2002. They find that intermediation spreads are closely linked to credit risk and regulatory requirements, but that improvements in bank efficiency and competition have had negligible effects. Their results are, however, based only on a descriptive, cross-country comparison of aggregate data.

Our descriptive data shows that, compared to other transition countries, the Kyrgyz banking sector has seen quite dramatic developments in nominal interest rates. The average lending rate in local currency was halved from $54 \%$ at the beginning of 1998 to just $26 \%$ at the end of 2005, while the deposit rate fell from $37 \%$ to just $8 \%$. Comparing lending and deposit rates shows, however, that the intermediation spread on local currency funds has remained constant at $18 \%$. Interest rates on foreign currency funds have also declined substantially. The interest rate on foreign currency loans has fallen from 43 to 18 percent, while the interest rate on deposits has fallen from 17 to 6 percent. As a result there has been a substantial contraction of the intermediation spread on foreign currency funds.

Our empirical analysis suggests that increased confidence in the banking sector has contributed significantly to reducing the deposit rates paid by banks. In contrast, we find that lower credit risk, intermediation costs and capital costs have not led to lower lending rates. The liberalization of the Kyrgyz financial sector seems to have been beneficial to both depositors and borrowers. The presence of foreign controlled banks has boosted confidence in the banking sector, and as a consequence has reduced deposit rates. Moreover, foreign banks charge significantly lower lending rates than domestic banks. Our results suggest further that Kyrgyz lending and deposit markets are far from competitive, despite the recent restructuring of the sector. Moreover, the recent reduction in banking sector concentration does not seem to have increased competition at all. As a consequence, banks' interest rates have not fully responded to lower market rates, which have been brought about by macroeconomic stabilization.

The paper is organized as follows: Section 2 derives conditions for equilibrium interest rates in a dual currency economy like Kyrgyzstan. Section 3 describes our empirical methodology and provides descriptive statistics for our data. Section 4 presents our empirical results and section 5 concludes.

\footnotetext{
${ }^{2}$ CIS-7 countries are Armenia, Azerbaijan, Georgia, Kyrgyzstan, Moldova, Tajikistan, and Uzbekistan.
} 


\section{Interest rates in a dual currency banking sector}

Like in many transition and developing countries, financial intermediation in Kyrgyzstan is conducted not only in local currency. Nearly three-quarters of private sector deposits mobilized by Kyrgyz banks are denominated in foreign currency, mostly in US dollars. The dollarization of lending is equally high, with foreign currency credit now making up 70 percent of total lending. Table 1 provides an overview of financial intermediation in Kyrgyzstan at the end of 2005.

Table 1. Financial intermediation in Kyrgyzstan, 12/2005*

\begin{tabular}{lr}
\hline Number of Banks & 20 \\
Total deposit volume (mln. Som) & $13^{\prime} 052$ \\
Deposits / GDP (in \%) & 13.0 \\
Foreign currency deposits (in \%) & 73 \\
& $7{ }^{\prime} 712$ \\
Total credit volume (mln. Som) & 7.7 \\
Credit / GDP (in \%) & 71 \\
Foreign currency credit (in \%) & $21 ' 709$ \\
Total assets of banks (mln. Som) & 35 \\
$\quad$ Customer Loans \\
Domestic Tbills \\
Foreign nostro accounts \\
$\quad$ of which \\
$\quad$
\end{tabular}

* Exchange rate Som/USD in December 2005: 41.3

With financial intermediation conducted in both local currency and foreign currency, how will Kyrgyz banks set interest rates? In Appendix A we provide a simple model of bank behavior in a two-currency financial sector. Similar to Catao (1998), we derive equilibrium interest rates from profit maximizing behavior of banks. ${ }^{3}$ In this section, we present the main results from our theoretical model, and use them to derive an empirical strategy for our analysis of interest rate developments in the Kyrgyz banking sector.

\footnotetext{
${ }^{3}$ In contrast to Catao (1998), we do not assume that the deposit market is completely competitive. By introducing the domestic currency T-bill rate and the foreign currency "nostro" rate as reference interest rates for banks and assuming that intermediation costs for lending and deposit taking are separable, we can analyze the impact of competitive conditions in the deposit and credit markets separately.
} 
We consider an economy in which banks mobilize deposits from households and allocate their loanable funds to four types of assets: local currency treasury-bills (T-bills), local currency loans to domestic firms, foreign currency deposit accounts with foreign banks (so called "nostro" accounts"), and foreign currency loans to domestic firms. This simple model reflects the asset allocation of Kyrgyz banks. Table 1 shows that at the end of 2005, $35 \%$ of consolidated banking assets were customer loans, $29 \%$ were nostro account balances, and $4 \%$ were domestic T-bills.

Assuming that the interest rate for T-bills $i_{T B}$, and that of nostro accounts $i_{N^{*}}$, are exogenous and that intermediation costs are separable, the deposit and lending markets can be analyzed separately. We assume tight currency exposure restrictions on banks so that the currency structure of assets and liabilities must be equal. Having mobilized a certain volume of local currency and foreign currency deposits, banks will then choose the volume of local currency loans so that their marginal revenue equals their exogenous revenue on local currency T-bills. Banks will likewise choose the volume of foreign currency loans so that their marginal revenue equals their exogenous revenue on foreign currency nostro accounts. Defining $\alpha_{L}\left(\alpha_{L^{*}}\right)$ as the default probability of local (foreign) currency loans, $\alpha_{T B}<\alpha_{L}$ as the domestic sovereign risk, $c_{L}\left(c_{L^{*}}\right)$ as the unit cost of underwriting these loans, and $k$ as the unit cost of regulatory capital, our model yields the following equilibrium lending rates:

[1] $\quad i_{L}=\left[i_{T B}+\left(\alpha_{L}-\alpha_{T B}\right)+c_{L}+k\right] \phi_{L}$

$$
i_{L^{*}}=\left\lfloor i_{N^{*}}+\alpha_{L^{*}}+c_{L^{*}}+k\right\rfloor \phi_{L^{*}}
$$

In conditions [1] and [2] the terms in parentheses define the local currency (foreign currency) lending rate under perfect competition. Due to credit risk, capital costs, and underwriting costs, the competitive local currency lending rate will be higher than the return on T-bills. Likewise the competitive foreign currency lending rate will be higher than the return on nostro accounts. In both markets, banks charge a mark-up above the competitive lending rate which depends on their market power in the respective credit market $\left(\phi_{L}, \phi_{L^{*}} \geq\right.$ 1). In our model the market power of banks is determined by concentration in the banking sector and the elasticity of local currency (foreign currency) credit demand. 
We assume that households store their savings either in cash or in bank accounts, which can both be held in local or foreign currency. ${ }^{4}$ Given the deposit rates for local currency $i_{D}$ and foreign currency $i_{D^{*}}$, a household's choice of savings technology then depends on its confidence in the banking system and its confidence in the local currency. We assume for simplicity that all households are risk neutral and have identical expectations concerning exchange rate movements. As a consequence deposits will only be mobilized in both currencies if the difference between the local currency and the foreign currency deposit rate compensates for expected depreciation (or appreciation) of the local currency $\Delta e$.

Banks mobilize savings up to the point where the marginal cost of deposit taking equals their marginal investment returns in either currency. Defining $r$ as the liquidity reserve requirement, and $c_{D}$ as the unit administrative cost of deposit mobilization, we yield the following equilibrium conditions for deposit rates:

$$
\begin{aligned}
& i_{D}=\left[\left(i_{T B}-\alpha_{T B}\right)(1-r)-c_{D}\right] \frac{1}{\phi_{D}(\lambda)} \\
& i_{D^{*}}=\left[i_{N^{*}}(1-r)-c_{D}\right] \frac{1}{\phi_{D}(\lambda)}
\end{aligned}
$$

In conditions [3] and [4] the term in parenthesis defines the competitive interest rate on local (foreign) currency deposits. Condition [3] tells us that even under perfect competition banks will offer depositors in local currency less than the T-bill rate, due to sovereign risk, liquidity requirements and administrative costs of deposit mobilization. Condition [4] shows that households will receive less on foreign currency deposits than the "nostro" rate, due to liquidity requirements and administrative costs of deposit mobilization. Moreover, if banks have market power $\left(\phi_{D}>1\right)$ they will further mark down deposit rates on both currencies. In our model the market power of banks in the deposit market again depends on the number of banks, and on the elasticity of deposit supply. The elasticity of deposit supply is hereby dependent on depositor's confidence in the domestic banking system, which we measure with the indicator $\lambda$. If households trust banks more, the supply of deposits is higher for each

\footnotetext{
${ }^{4}$ We assume, as is the case of Kyrgyzstan, that households can freely choose between deposits in foreign and local currency. We further assume that households cannot invest directly in government T-bills. This reflects reality in the Kyrgyz Republic where the majority of T-bills are held by few banks and the secondary market is practically inexistent.
} 
interest rate. More trust in the banking system will thus lead to a higher elasticity of deposit supply, ceteris paribus, and thus to lower equilibrium deposit rates.

Concerning structural reforms to the banking sector, our theoretical model suggests that an increase in the trustworthiness of banks should reduce both local currency and foreign currency deposit rates, while a reduction of intermediation costs should raise them. Moreover, structural reforms which reduce credit risk, intermediation costs and capital costs will reduce both local currency and foreign currency lending rates. The model further predicts that banks' local (foreign) currency interest rates should be positively related to domestic (foreign) market rates. However, the reaction of banks' interest rates to market rates (and structural changes) will depend on the competitiveness of the deposit and credit markets. If banks have no market power at all, changes in market rates will be passed on one to one. If, however, banks have market power, then the reaction of their interest rates will be lower.

\section{Methodology and Data}

Our empirical analysis is based on quarterly, bank-level data obtained from the National Bank of the Kyrgyz Republic (NBKR) for the period 1998-2005. ${ }^{5}$ We conduct separate analysis for local and foreign currency deposit rates (Som deposits, Foreign deposits), as well as for local and foreign currency lending rates (Som credit, Foreign credit). As suggested by our theoretical model we relate banks interest rates to domestic (foreign) market rates, banklevel indicators of trustworthiness, intermediation costs and credit risk, to prudential requirements on liquidity provision and capital requirements, and finally to competitive conditions in the banking sector. In the following we describe our dependant and explanatory variables in detail. Appendix B provides detailed definitions and sources for all variables.

\section{Banks' interest rates}

We examine mean interest rates per bank on new deposits from the private sector and loans to the private sector per quarter. By looking at interest rates on flows rather than stocks, our data more accurately reflects the current interest rate settings for each bank in each

\footnotetext{
5 We limit our analysis to those banks which are primarily involved in financial intermediation within Kyrgyzstan. As a consequence we exclude the information from 2 banks from our data set.
} 
period. ${ }^{6}$ Figure 1 plots the weighted average interest rate on new local currency deposits (Som deposits) and loans (Som credit) by quarter for the period 1998-2005. The picture shows two interesting features: First, the interest rate level for both loans and deposits has fallen substantially. Since 1998 lending rates have been halved from over 50\% to 26\%. Deposit rates have also dropped significantly from around $35 \%$ to just $8 \%$. The second interesting feature of figure 1 is that there does not seem to have been a substantial decline in the intermediation spread since 1998. Indeed the spread between mean lending and deposit rates displays a similar level of $18 \%$ at the beginning and end of our observation period. The spread did experience substantial volatility between 1998 and 2002, reaching a low of $-3 \%$ and a high of $28 \%$. Over the past three years the intermediation spread has remained stable at levels between 16 and $19 \%$.

\section{Figure 1. Interest Rates - Som}

Variable definitions: See Appendix B for detailed definitions and sources. Som Deposits/ Som Credit: weighted mean interest rate across banks per quarter. Som Spread: Som Credit - Som Deposits. See Appendix B for detailed definitions and sources.

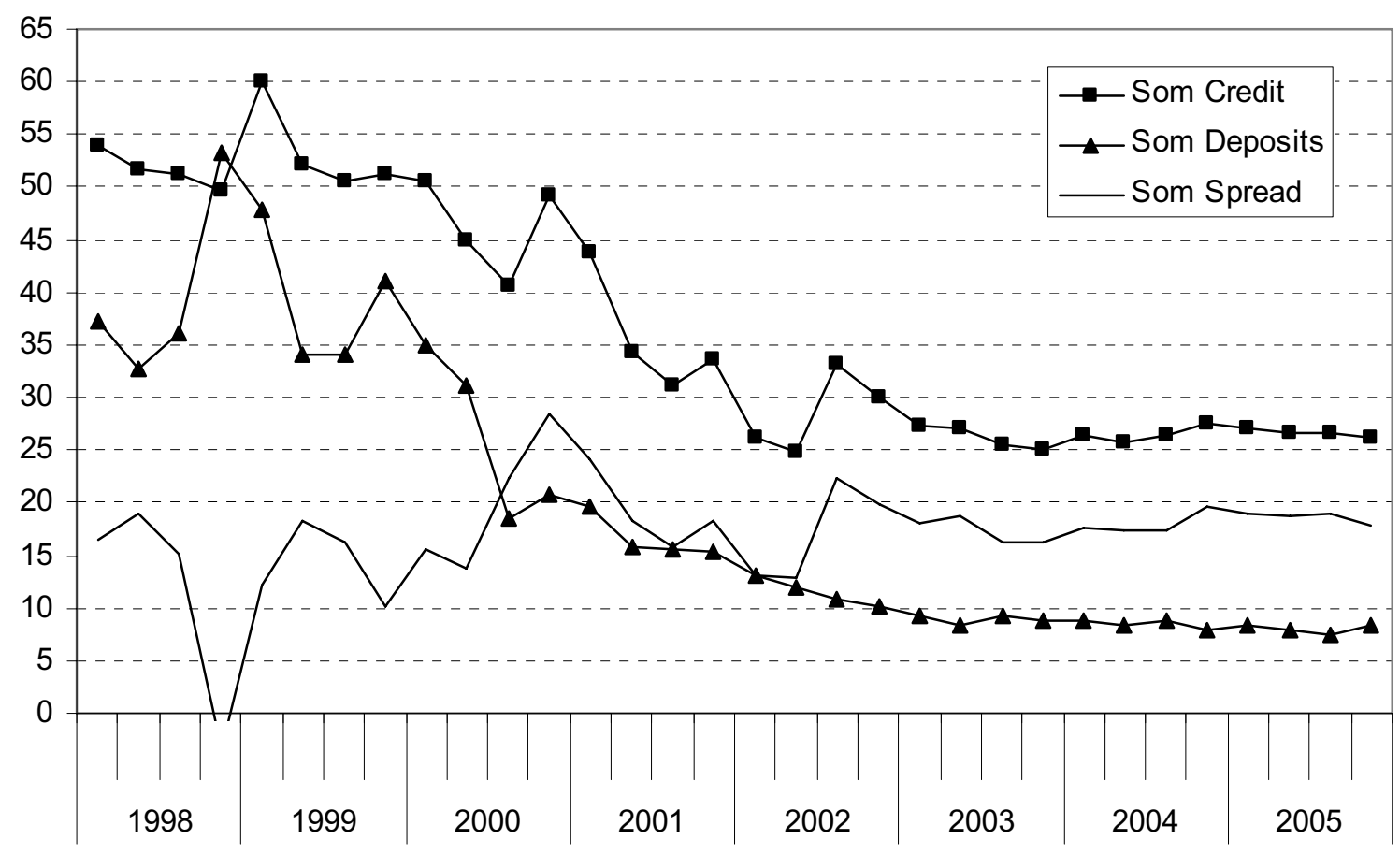

\footnotetext{
${ }^{6}$ Our analysis also excludes interest rates on demand deposits as complete interest rate data on these was not available. Robustness checks including demand deposits, based on interest rates of deposits stocks yield the same qualitative results.
} 
Figure 2 plots the weighted average interest rate on new foreign currency deposits (Foreign deposits) and loans (Foreign credit) by quarter for the period 1998-2005. The figure shows that foreign currency lending rates have fallen from over $40 \%$ in 1998 to $18 \%$ at the end of 2005. Interest rates on deposits have also decreased, but by a far lower margin. From an initial level of $15 \%$ they climbed shortly to $20 \%$ at the end of 1998 , and have since fallen to roughly $6 \%$. In contrast to local currency funds the intermediation spread on foreign currency funds has fallen substantially. Between 1998 and 2001 bank's intermediation spreads on foreign currency funds exceeded $20 \%$. Since 2002 , this spread has declined steadily to around $12 \%$. Thus while the spread on foreign currency funds was substantially higher than that on local currency funds prior to 2000 , it has now reached lower levels.

\section{Figure 2. Interest Rates - Foreign Currency}

Variable definitions: See Appendix B for detailed definitions and sources. Foreign Deposits/ Foreign Credit: weighted mean interest rate across banks per quarter. Foreign Spread: Foreign Credit - Foreign Deposits. See Appendix B for detailed definitions and sources.

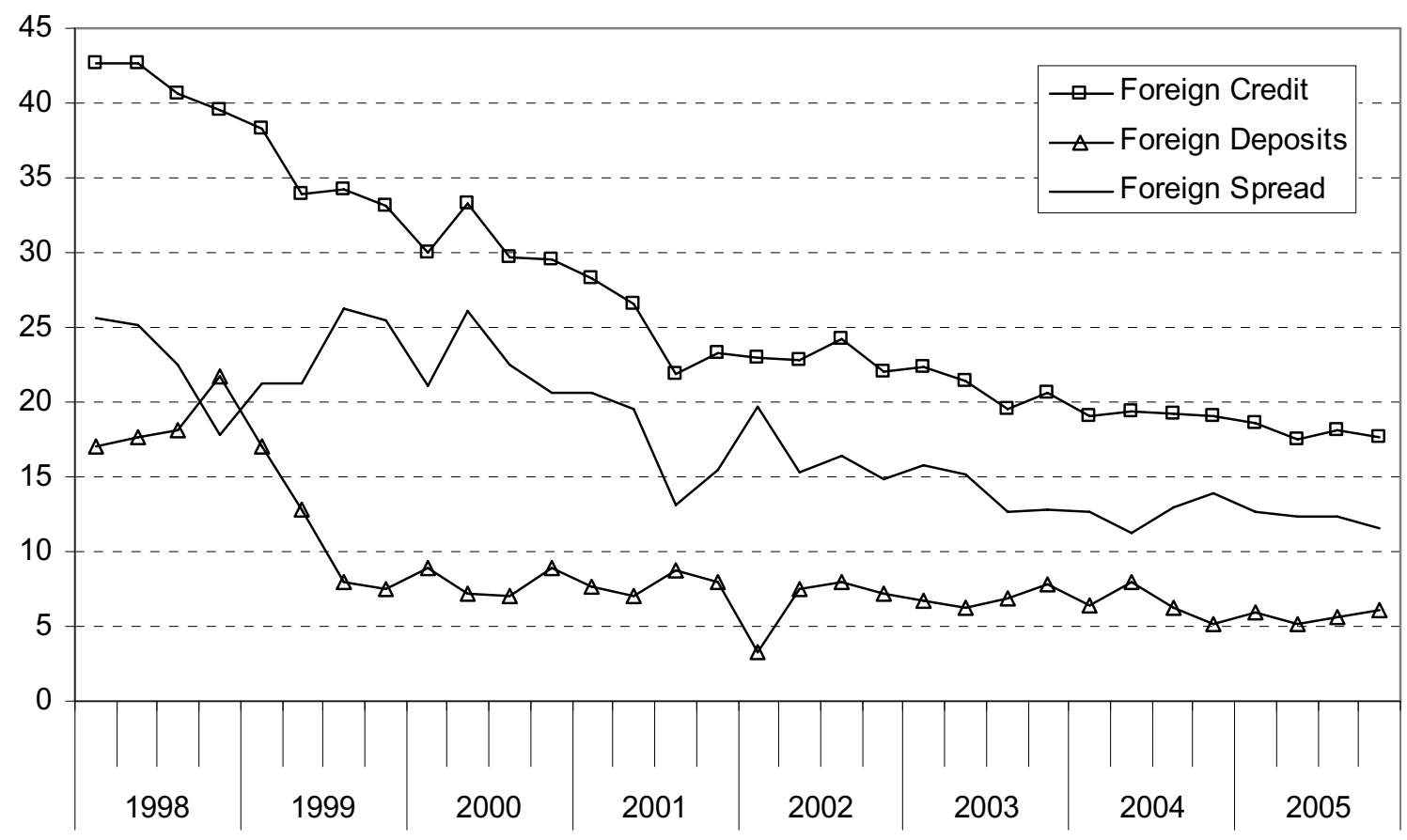

\section{Market interest rates}

Our model suggests that banks' local currency interest rates will be positively related to domestic market rates. Indeed, the developments in local currency deposit and lending interest rates, observed in Figure 1, may simply reflect the general decline in domestic market rates 
due to recent macroeconomic stabilization in Kyrgyzstan. At the beginning of our observation period in 1998 the interest rate on 3-month treasury bills of the Kyrgyz Republic stood at $41 \%$, as a consequence of a high government budget deficit and an inflation rate of close to $40 \%$. By 2005 this market rate had declined to just 4.3\%, reflecting low inflation and a more balanced government budget. We capture the impact of domestic market rates on banks lending and deposit rates with the variable T-Bill rate. This captures the weighted average interest rate on new 3-month treasury bills in each quarter. Table 2 displays the mean value of T-Bill rate by year for our entire observation period.

Our model further suggests that banks' foreign currency interest rates will be positively related to international market rates. Indeed, international interest rate developments may explain the drop in interest rate levels for foreign currency deposits and loans in Kyrgyzstan. We capture the impact of international interest rates on Kyrgyz bank's interest rates with the dependent variable USD Rate. This measures the average Euro market interest rate on 3 month US Dollar investments. Table 2 shows that USD Rate declined sharply between 2000 and 2004, in line with the observed fall in Kyrgyz interest rates for foreign currency funds

\section{Table 2. Summary statistics of explanatory variables}

Variable definitions: see Appendix B for detailed definitions and sources. All values reported are mean values per year based on quarterly data from sample. For reasons of exposition the variable Assets in table 2 reports assets valued in million 1998 Som, rather than the $\log$ value as used in our regression analysis.

\begin{tabular}{lrrrrrrrr}
\hline & 1998 & 1999 & 2000 & 2001 & 2002 & 2003 & 2004 & 2005 \\
\hline T Bill rate & 41.2 & 46.7 & 32.4 & 18.2 & 10.8 & 7.1 & 4.9 & 4.3 \\
USD rate & 5.4 & 5.3 & 6.4 & 3.8 & 1.7 & 1.1 & 1.5 & 3.5 \\
& & & & & & & & \\
Banks & 19 & 22 & 20 & 18 & 18 & 18 & 18 & 18 \\
Foreign Bank & 1 & 3 & 3 & 4 & 4 & 6 & 6 & 8 \\
State Bank & 3 & 4 & 4 & 3 & 3 & 2 & 2 & 1 \\
& & & & & & & & \\
Assets & 1.8 & 1.3 & 1.1 & 1.2 & 1.6 & 1.8 & 2.7 & 3.6 \\
Substandard credit & .03 & .25 & .09 & .06 & .11 & .15 & .08 & .04 \\
Foreign funding / Assets & .05 & .02 & .01 & .00 & .01 & .01 & .04 & .07 \\
& & & & & & & & \\
Liquidity reserves & .16 & .12 & .09 & .09 & .10 & .10 & .10 & .10 \\
Capital / Loans & .39 & .32 & .33 & .54 & .72 & .66 & .42 & .38 \\
Loans / Assets & .49 & .46 & .45 & .47 & .40 & .40 & .50 & .50 \\
& & & & & & & & \\
Concentration som deposits & .12 & .11 & .12 & .10 & .11 & .11 & .11 & .12 \\
Concentration forex deposits & .16 & .11 & .10 & .12 & .14 & .14 & .10 & .09 \\
Concentration som credit & .13 & .11 & .10 & .10 & .11 & .10 & .10 & .17 \\
Concentration forex credit & .18 & .13 & .12 & .16 & .17 & .14 & .14 & .13 \\
\hline
\end{tabular}




\section{Confidence in banks}

Our model suggests that stronger public confidence in the banking sector should allow banks to pay lower deposit rates. Indeed, De Nicolo et al. (2003) argue that a lack of trust in the banking sector may be the main cause of high interest rates in low-income transition countries such as Kyrgyzstan. We have no survey data on household confidence in the banking sector. We therefore include a simple indicator of trustworthiness: bank ownership. The dummy variable State Bank is only 1 if a bank is majority owned by the state, while the dummy variable Foreign Bank is only 1 if the majority of the bank's shares lie in foreign hands. Due to the collapse of several private domestic banks in the mid 1990's the Kyrgyz public may be more likely to trust state banks and foreign owned banks. If this is the case we should find that state-owned and foreign-owned banks can afford to pay lower interest rates on deposits. Table 2 shows that the share of foreign-owned institutions in the Kyrgyz banking sector has increased steadily since 1998, with now nearly half of all banks under foreign control. At the same time, the share of state-owned banks has decreased. The increased presence of foreign-owned banks may have contributed to higher confidence in the banking sector and thus lower deposit rates.

\section{Intermediation costs and credit risk}

Our model suggests that a reduction in banks' intermediation costs should lead to higher deposit rates and lower lending rates for local currency and foreign currency funds. Our dataset does not provide us with separate information on the costs of mobilizing deposits and underwriting loans. As a bank-level indicator of intermediation costs we therefore use bank size, measured by the log of the real value of total bank Assets. Assuming that there are scale economies in retail banking larger banks should be able to offer lower lending rates and higher deposit rates than smaller banks.

Our model suggests that a reduction in the credit risk of banks should lead to lower lending rates on local and domestic currency funds. Our data includes a bank level indicator of credit risk: the ratio of Substandard credit to total credit. The NBKR classifies loans as substandard if they are in arrears for more than 30 days. $^{7}$ Table 2 shows that this measure of credit risk has experienced strong ups and downs since 1998. The strong increase in bad loans

\footnotetext{
${ }^{7}$ Classification as "substandard" can also be based on prolonging of loans, changes in value of pledges among others.
} 
in 1999 reflects the negative effect of the Russian crisis on asset quality. The increase between 2001 and 2003 may reflect a more lax lending policy of banks following macroeconomic stabilization. More recently, the average share of substandard credit has decreased substantially, suggesting a strong improvement in bank portfolio quality.

\section{Access to international funds}

In our analysis of lending rates we further control for banks' access to international funding. Since 2000 Kyrgyz banks have received an increasing amount of funding from international financial institutions and banks. Some of this funding has been at concessional rates, for example for SME lending, and may therefore affect the lending rates charged by banks when disbursing these funds. In our estimation of lending rates we therefore include the variable Foreign Funds / Assets which measures the ratio of funding a bank receives from foreign financial institutions to its total assets. This variable allows us to analyze whether access to (cheaper) international funds has reduced lending rates.

\section{Prudential Requirements}

In accordance with the Basel principles, Kyrgyz banks are subject to prudential requirements on capital size, capital-asset ratio, liquidity reserves, currency position, exposure per borrower, and concentration of deposits. Our model suggests that, in particular, regulations on liquidity provision and minimum capital should affect banks' deposit and lending deposit rates.

A reduction in regulatory requirements on liquidity reserves since 1998 may have affected the interest rates paid by banks to depositors. Prior to 2001 the minimum reserve ratio was set by the NBKR at 20 percent after which it was reduced to 10 percent. However, due to varying remuneration of required reserves by the NBKR, changes in the effective reserve rate were more frequent and more gradual. We take this into account by using the mean effective liquidity reserve ratio per quarter, i.e. the reserve rate adjusted for remuneration of reserves, as our measure of prudential liquidity requirements. ${ }^{8}$ Table 2 shows that on average this variable Liquidity reserves has remained fairly constant since 2001.

\footnotetext{
${ }^{8}$ We use this sector level measure of liquidity requirements rather than actual liquidity position of banks as prior to 2002 we do not have access to the necessary balance sheet data to calculate bank-specific liquidity positions.
} 
Our model suggests that banks will charge borrowers for the opportunity cost of regulatory capital. An obvious indicator of capital costs would be the minimum capital/ asset ratio set by the NBKR. This ratio was increased from 8 to 12 percent in 1999. However, in practice this minimum capital ratio has not always been completely binding. Before 2001 many banks could only gradually meet these requirements, while more recently they are "over-capitalized". For this reason we use the actual ratio of Capital / Loans as our indicator of regulatory capital costs. We also include the bank specific ratio of Loans/Assets to control for differences in the asset structure across banks. Table 2 shows that the ratio of bank capital to loans has almost been halved since 2000, suggesting that banks are now more leveraged, which may have contributed to lower lending rates.

\section{Competition}

Our theoretical model suggests that the impact of market interest rates, intermediation costs, credit risk, and prudential requirements on banks' interest rates depends strongly on competitive conditions in the banking sector. If banks have negligible market power, changes in market rates, intermediation costs and liquidity requirements should be passed on to depositors one to one. Likewise, changes in market rates, intermediation costs, credit risk, and capital costs should be passed on one to one to lenders. The stronger the market power of banks, the weaker the reaction of their interest rates should be to our explanatory variables described above. Based on this theoretical result, a range of studies have judged banking sector competitiveness, by the reaction of deposit and lending rates in particular to changes in market interest rates (see Freixas and Tirole, 1998 for a discussion of such studies). We follow this strategy in our empirical analysis by judging the level of competitiveness in the Kyrgyz deposit and credit market from the reaction of banks local (foreign) currency interest rates to the $T$-Bill rate (USD rate).

In addition we directly test whether changes in banking sector competitiveness increase the impact of our previous explanatory variables on banks' interest rates. We do this by constructing a direct measure of banking sector competitiveness and interacting this with our measure of market interest rates. We measure the competitiveness of all four of our market segments (som deposits, foreign currency deposits, som credit, and foreign currency credit) with the variable Concentration. This measures the Herfindahl-Hirschman Index (HHI) of concentration for outstanding loans (deposits) in each quarter. Table 2 shows that this measure of concentration is quite low for all our four market segments. With 18 banks in our 
sample, the minimum possible value of the HHI (indicating no market power) would be 0.06 , while the maximum would be $1 .{ }^{9}$ Table 2 shows that the actual HHI for all four market segments lay below 0.2. The concentration in the local currency deposit market does not seem to have changes much in the past five years, while that in the local currency credit market has actually increased. In contrast concentration in the foreign currency deposit and credit market has declined.

\section{Results}

Tables 3-6 report OLS estimates for our four dependant variables Som deposits, Foreign deposits, Som credit and Foreign credit respectively. In all four tables the standard errors of our estimated coefficients are adjusted for cluster effects at bank level. As banks' deposit (lending) rates maybe affected by the maturity of their deposits (loans) all regressions control for the average maturity of banks' relevant liabilities (assets).

\section{Local currency deposits}

Table 3 reports our regression results for Som deposits with column (1) displaying results for our baseline model. As expected, the local currency deposit rate is significantly and positively correlated with the T-Bill rate. Our point estimate of .563 shows, however, that deposit rates by no means react fully to changes in market rates. This suggests that there is only weak competition among banks for deposits. Further results in column (1) show that increased public confidence in the banking sector has contributed to lowering deposit rates. We expect that deposit rates are lower for state and foreign-owned banks, as depositors may trust these more than they do private domestic banks. Table 3 shows that foreign controlled banks and state controlled banks do pay significantly lower deposit rates than domestic private banks. The negative and significant coefficient on Assets contradicts our prediction that larger banks are able to pay higher deposit rates because they have lower average

\footnotetext{
${ }^{9}$ We use the following definition of the Herfindahl- Hirschmann Index, where $a_{i}$ is the market share of bank $i$ :

$H H I=\frac{\sum_{i=1}^{N} a_{i}^{2}}{\left(\sum_{i=1}^{N} a_{i}\right)^{2}}$. This index takes values of $1 / \mathrm{N}$ (minimum concentration) to 1 (maximum concentration).
} 
intermediation costs. One explanation for the negative correlation between asset size and interest rates may be that bank size is not only an indicator for efficiency, but also for trustworthiness. Small banks may be less trustworthy, and therefore may have to pay more to attract deposits. The positive coefficient of Liquidity reserves contradicts our prediction that the (slight) reduction in effective requirements on liquidity reserves may have led to higher interest rates for depositors. All in all our baseline results suggest that the nominal fall in local currency deposit rates since 1998 has been fuelled by the decline in market interest rates, which reflect macroeconomic stabilization, as well as increased confidence in the banking sector. In contrast, the results suggest that neither lower liquidity requirements nor lower intermediation costs have increased the remuneration of depositors.

\section{Table 3. Local currency deposits}

The table reports OLS estimates for interest rates on new deposits in Kyrgyz Som using quarterly data for 1998-2005. See Appendix B for detailed definitions and sources of all variables. Each regression controls for the average maturity of new deposits. Robust t-statistics are reported in parenthesis based on standard errors which are adjusted for cluster effects at the bank level. One star denotes significant at $10 \%$ level; two stars significant at $5 \%$ level; three stars significant at $1 \%$ level.

\begin{tabular}{|c|c|c|c|c|c|}
\hline & $\begin{array}{c}(1) \\
\text { baseline }\end{array}$ & $\begin{array}{c}(2) \\
1998-2001\end{array}$ & $\begin{array}{c}(3) \\
2002-2005\end{array}$ & $\begin{array}{c}(4) \\
\text { bank fixed } \\
\text { effects }\end{array}$ & $\begin{array}{c}(5) \\
\text { concentration }\end{array}$ \\
\hline T-Bill rate & $\begin{array}{c}0.555 \\
(18.75)^{\star * *}\end{array}$ & $\begin{array}{c}0.421 \\
(10.29)^{* * *}\end{array}$ & $\begin{array}{l}-0.002 \\
(0.03)\end{array}$ & $\begin{array}{c}0.529 \\
(21.48)^{* * *}\end{array}$ & $\begin{array}{c}0.321 \\
(3.11)^{* * *}\end{array}$ \\
\hline Foreign bank & $\begin{array}{c}-5.156 \\
(4.12)^{\star * \star}\end{array}$ & $\begin{array}{l}-12.347 \\
(7.12)^{\star * *}\end{array}$ & $\begin{array}{l}-1.283 \\
(2.53)^{* *}\end{array}$ & $\begin{array}{c}-6.956 \\
(3.54)^{* * *}\end{array}$ & $\begin{array}{c}-5.146 \\
(4.08)^{\star * *}\end{array}$ \\
\hline State bank & $\begin{array}{l}-2.869 \\
(1.84)^{*}\end{array}$ & $\begin{array}{l}-3.987 \\
(1.91)^{*}\end{array}$ & $\begin{array}{c}-1.969 \\
(3.18)^{\star * *}\end{array}$ & $\begin{array}{l}-4.486 \\
(1.86)^{*}\end{array}$ & $\begin{array}{l}-2.901 \\
(1.85)^{*}\end{array}$ \\
\hline Assets & $\begin{array}{l}-1.273 \\
(2.32)^{\star \star}\end{array}$ & $\begin{array}{l}-0.811 \\
(0.95)\end{array}$ & $\begin{array}{c}-0.987 \\
(3.34)^{\star \star \star}\end{array}$ & $\begin{array}{l}-1.139 \\
(1.76)^{*}\end{array}$ & $\begin{array}{l}-1.250 \\
(2.31)^{* \star}\end{array}$ \\
\hline $\begin{array}{l}\text { Liquidity } \\
\text { reserves }\end{array}$ & 1.073 & 0.998 & -18.709 & 0.857 & 1.001 \\
\hline & $(6.14)^{* * *}$ & $(5.83)^{* * *}$ & $(5.84)^{\star * *}$ & $(5.47)^{* * *}$ & $(5.77)^{\star * *}$ \\
\hline $\begin{array}{l}\text { Concentration } \\
{ }^{*} \text { T-Bill rate }\end{array}$ & & & & & 2.092 \\
\hline Constant & $\begin{array}{r}-3.616 \\
(1.51) \\
\end{array}$ & $\begin{array}{l}3.804 \\
(1.33)\end{array}$ & $\begin{array}{l}188.209 \\
(6.03)^{\star * *}\end{array}$ & $\begin{array}{l}4.441 \\
(1.38)\end{array}$ & $\begin{array}{l}(2.59)^{* *} \\
-2.918 \\
(1.24)\end{array}$ \\
\hline $\begin{array}{l}\text { Observations } \\
\text { R-squared }\end{array}$ & $\begin{array}{l}559 \\
0.79 \\
\end{array}$ & $\begin{array}{l}280 \\
0.59 \\
\end{array}$ & $\begin{array}{l}279 \\
0.63 \\
\end{array}$ & $\begin{array}{l}559 \\
0.83 \\
\end{array}$ & $\begin{array}{l}559 \\
0.79 \\
\end{array}$ \\
\hline
\end{tabular}

Columns (2) and (3) of table 3 split our sample into the two periods 1998-2001 and 2002-2004. This allows us to examine whether the determinants of local currency deposit rates have changed following the restructuring of the banking system in the aftermath of the Russian financial crisis. The results reported in the two tables suggest that is actually the case. 
The reaction of the deposit rate to changes in the T-bill rate is substantially stronger in the period 1998-2001 than in the period 2002-2005. Column 2 shows that in the period 19982001 the strong decline in the domestic treasury bill rate $(41 \%$ to $18 \%)$ had a significant impact on deposit rates. In contrast the low and insignificant coefficient of T-Bill rate in column (3) suggests that further fall in the T-bill rate from $10 \%$ to $4 \%$ between 2002 and 2005, had no impact on deposit rates at all! These results confirm that competition in the Kyrgyz deposit market is weak, and if anything, the market has become less competitive over time. Structural differences between banks do have a significant impact on deposit rates between 2002 and 2005. The coefficients of Foreign bank, State bank and Assets are all negative and significant suggesting that more trustworthy banks were able to pay lower deposit rates.

Column (4) of the table examines our full data set again, but adds bank fixed effects to our baseline model. We introduce bank fixed effects in order to control for omitted bankspecific characteristics which may bias our results. The results reported in column (4) confirm those of our baseline regression both qualitatively and quantitatively. The estimated coefficient for T-Bill rate is significant and similar in size to that in our baseline regression. Moreover, the coefficients on Foreign bank, State bank and Assets all remain negative and significant, supporting our baseline finding that increased trust in banks has reduced deposit rates.

Finally, column (5) of the table reports results of a full sample regression in which we include the interaction term Concentration*T-Bill rate. This specification allows us to directly test our theoretical prediction that the reaction of deposit rates to the T-bill rate depends on the level of competition between banks. If this is the case we expect a negative sign on the interaction term Concentration*T-Bill rate; higher concentration would imply that market rate changes are passed on less to depositors and borrowers. The positive and significant coefficient of the interaction term in column (5) contradicts the prediction that more concentration reduces the reaction of the deposit rates to market rates. An explanation for this result may be that our measure of concentration is a weak indicator of actual market competitiveness.

\section{Foreign currency deposits}

Table 4 presents our estimation results for Foreign deposits, displaying the same five specifications as in table 3 . The results generally resemble those for local currency deposit 
rates. Foreign currency deposit rates are positively correlated with the Euro-Market USD rate, suggesting that international interest rate developments have contributed to lowering foreign currency deposit rates in Kyrgyzstan. Again though, the point estimate of .572 in our baseline regression suggests that the deposit market is by no means very competitive. The table further shows that foreign and state owned banks pay significantly lower interest rates on foreign currency deposits than domestic banks, while larger banks pay lower interest rates than smaller banks. This confirms our previous finding that more trust in foreign owned and larger banks may have contributed to lowering deposit rates overall.

\section{Table 4. Foreign currency deposits}

The table reports OLS estimates for interest rates on new deposits in foreign currency using quarterly data for 1998-2005. See Appendix B for detailed definitions and sources of all variables. Each regression controls for the average maturity of new deposits. Robust t-statistics are reported in parenthesis based on standard errors which are adjusted for cluster effects at the bank level. One star denotes significant at 10\% level; two stars significant at 5\% level; three stars significant at $1 \%$ level.

\begin{tabular}{|c|c|c|c|c|c|}
\hline & $\begin{array}{c}(1) \\
\text { baseline }\end{array}$ & $\begin{array}{c}(2) \\
1998-2001\end{array}$ & $\begin{array}{c}(3) \\
2002-2005\end{array}$ & $\begin{array}{c}(4) \\
\text { bank fixed } \\
\text { effects }\end{array}$ & $\begin{array}{c}(5) \\
\text { concentration }\end{array}$ \\
\hline USD rate & $\begin{array}{c}0.572 \\
(3.66)^{\star \star *}\end{array}$ & $\begin{array}{l}-0.001 \\
(0.00)\end{array}$ & $\begin{array}{c}0.548 \\
(2.43)^{* *}\end{array}$ & $\begin{array}{c}0.486 \\
(6.11)^{* * *}\end{array}$ & $\begin{array}{l}0.224 \\
(0.73)\end{array}$ \\
\hline Foreign bank & $\begin{array}{c}-3.886 \\
(4.43)^{\star \star \star}\end{array}$ & $\begin{array}{c}-7.487 \\
(9.82)^{\star * *}\end{array}$ & $\begin{array}{l}-2.265 \\
(1.84)^{*}\end{array}$ & $\begin{array}{c}-3.233 \\
(3.44)^{\star \star \star}\end{array}$ & $\begin{array}{c}-3.959 \\
(4.63)^{\star * \star}\end{array}$ \\
\hline State bank & $\begin{array}{r}-1.057 \\
(0.61)\end{array}$ & $\begin{array}{r}-1.573 \\
(0.89)\end{array}$ & $\begin{array}{l}-1.032 \\
(0.40)\end{array}$ & $\begin{array}{l}-2.398 \\
(2.58)^{* *}\end{array}$ & $\begin{array}{l}-0.966 \\
(0.56)\end{array}$ \\
\hline Assets & $\begin{array}{l}-1.040 \\
(3.04)^{* * *}\end{array}$ & $\begin{array}{l}-1.186 \\
(2.30)^{\star *}\end{array}$ & $\begin{array}{l}-0.963 \\
(1.97)^{*}\end{array}$ & $\begin{array}{c}-1.811 \\
(4.93)^{\star \star \star}\end{array}$ & $\begin{array}{c}-1.112 \\
(3.19)^{\star * *}\end{array}$ \\
\hline $\begin{array}{l}\text { Liquidity } \\
\text { reserves }\end{array}$ & 1.368 & 1.290 & -1.698 & 1.197 & 1.304 \\
\hline & $(8.37)^{\star * \star}$ & $(8.52)^{\star * *}$ & $(0.56)$ & $(11.92)^{\star \star \star}$ & $(7.78)^{\star * *}$ \\
\hline $\begin{array}{l}\text { Concentration } \\
{ }^{*} \text { USD rate }\end{array}$ & & & & & 3.194 \\
\hline Constant & $\begin{array}{c}-7.542 \\
(3.82)^{\star \star \star}\end{array}$ & $\begin{array}{r}-2.746 \\
(1.09) \\
\end{array}$ & $\begin{array}{c}21.462 \\
(0.73) \\
\end{array}$ & $\begin{array}{l}-1.526 \\
(1.01) \\
\end{array}$ & $\begin{array}{c}(1.66) \\
-6.887 \\
(3.40)^{\star * *}\end{array}$ \\
\hline Observations & 514 & 264 & 250 & 514 & 514 \\
\hline R-squared & 0.56 & 0.54 & 0.28 & 0.68 & 0.56 \\
\hline
\end{tabular}

Table 4 displays one major difference to our results for local currency deposits. Our sample split in columns (2) and (3) show that interest rates on foreign currency deposits are more closely related to international interest rates in the period after 2002 than beforehand. Indeed, the coefficient of USD rate in column (2) suggests that prior to 2002 there was no significant correlation between international interest rates and foreign currency deposit rates at all. This finding stands in stark contrast to the impact of domestic T-bill rates on local 
currency deposit rates, where we find a stronger impact prior to 2002. One explanation is that during the period 1998-2001 the rates that banks had to pay for foreign currency deposit were influenced more by domestic instability than their potential earnings on these funds abroad.

\section{Lending rates}

Table 5 reports our estimation results for Som credit. As in the previous tables, we conduct five analyses, examining our basic model in column (1), splitting the data set in columns (2) and (3), introducing bank fixed-effects in column (4), and finally adding the interaction term of Concentration*T-Bill rate to our baseline regression in column (5). We find that local currency lending rates are significantly and positively correlated with the T-Bill rate in all specifications. The point estimates of around or below .5 for T-Bill rate in all columns suggest, however, that lending rates have only partly reacted to falling domestic market rates. This result suggests that, like the deposit market, the Kyrgyz credit market is also characterized by weak competition. The results for our bank-level explanatory variables are in line with those reported for deposit rates. We find that Foreign bank and State bank display negative signs, suggesting that lower cost of funds for more trustworthy banks does translate into lower lending rates. However, only the estimates for Foreign bank are significant. We also find a negative coefficient of Assets on lending rates suggesting that larger banks charge lower interest rates. This may again reflect lower funding costs of larger banks that may be more trustworthy. The negative coefficient on Assets would, however, also confirm our prediction that larger banks charge lower lending rates because they have lower average intermediation costs. The insignificant coefficients on Substandard credit, Capital/Loans, and Foreign funds / Assets contradict our predictions that improved credit risk, lower capital costs and access to (partly subsidized) foreign funds have contributed to reducing local currency lending rates. Finally, the insignificant interaction term Concentration*T-Bill rate in column (5) suggests that recent increases in concentration in the local currency credit market have not affected its competitiveness. 


\section{Table 5. Local currency credit}

The table reports OLS estimates for interest rates on new loans in Kyrgyz Som using quarterly data for 1998-2005. See Appendix B for detailed definitions and sources of all variables. Each regression controls for the average maturity of new deposits. Robust t-statistics are reported in parenthesis based on standard errors which are adjusted for cluster effects at the bank level. One star denotes significant at $10 \%$ level; two stars significant at $5 \%$ level; three stars significant at $1 \%$ level.

\begin{tabular}{|c|c|c|c|c|c|}
\hline & $\begin{array}{c}(1) \\
\text { baseline }\end{array}$ & $\begin{array}{c}(2) \\
1998-2001\end{array}$ & $\begin{array}{c}(3) \\
2002-2005\end{array}$ & $\begin{array}{c}(4) \\
\text { bank fixed } \\
\text { effects }\end{array}$ & $\begin{array}{c}\text { (5) } \\
\text { concentration }\end{array}$ \\
\hline T-Bill rate & $\begin{array}{c}0.493 \\
(7.55)^{* * *}\end{array}$ & $\begin{array}{c}0.364 \\
(4.45)^{* * *}\end{array}$ & $\begin{array}{l}0.536 \\
(1.54)\end{array}$ & $\begin{array}{c}0.431 \\
(5.84)^{* * *}\end{array}$ & $\begin{array}{c}0.522 \\
(3.37)^{* * *}\end{array}$ \\
\hline Foreign bank & $\begin{array}{l}-5.615 \\
(2.71)^{* *}\end{array}$ & $\begin{array}{l}-4.076 \\
(0.59)\end{array}$ & $\begin{array}{c}-4.363 \\
(2.49)^{* *}\end{array}$ & $\begin{array}{l}0.756 \\
(0.18)\end{array}$ & $\begin{array}{l}-5.676 \\
(2.68)^{* *}\end{array}$ \\
\hline State bank & $\begin{array}{r}-4.809 \\
(1.17)\end{array}$ & $\begin{array}{l}-7.557 \\
(1.79)^{*}\end{array}$ & $\begin{array}{l}2.262 \\
(0.79)\end{array}$ & $\begin{array}{r}-1.447 \\
(0.28)\end{array}$ & $\begin{array}{l}-4.824 \\
(1.15)\end{array}$ \\
\hline Assets & $\begin{array}{l}-2.474 \\
(2.68)^{* *}\end{array}$ & $\begin{array}{l}-1.864 \\
(1.05)\end{array}$ & $\begin{array}{l}-1.355 \\
(2.10)^{*}\end{array}$ & $\begin{array}{l}-4.066 \\
(2.07)^{*}\end{array}$ & $\begin{array}{l}-2.463 \\
(2.65)^{* *}\end{array}$ \\
\hline $\begin{array}{l}\text { Substandard } \\
\text { credit }\end{array}$ & -13.925 & -13.546 & 0.983 & -10.526 & -14.037 \\
\hline Capital/Loans & $\begin{array}{r}(1.39) \\
-0.260 \\
(1.22)\end{array}$ & $\begin{array}{l}(0.71) \\
-0.623 \\
(1.20)\end{array}$ & $\begin{array}{r}(0.15) \\
-0.212 \\
(1.60)\end{array}$ & $\begin{array}{c}(1.24) \\
-0.156 \\
(2.26)^{* *}\end{array}$ & $\begin{array}{l}(1.41) \\
-0.258 \\
(1.20)\end{array}$ \\
\hline Loans/Assets & $\begin{array}{l}-7.807 \\
(1.28)\end{array}$ & $\begin{array}{l}-9.381 \\
(0.96)\end{array}$ & $\begin{array}{l}-9.975 \\
(1.88)^{*}\end{array}$ & $\begin{array}{l}-7.427 \\
(1.06)\end{array}$ & $\begin{array}{r}-7.820 \\
(1.28)\end{array}$ \\
\hline $\begin{array}{l}\text { Foreign } \\
\text { funds/Assets }\end{array}$ & 19.386 & 16.883 & 15.842 & 30.777 & 19.290 \\
\hline & (1.15) & $(0.59)$ & (0.91) & $(1.92)^{*}$ & (1.13) \\
\hline $\begin{array}{l}\text { Concentration } \\
{ }^{*} \mathrm{~T} \text {-Bill rate }\end{array}$ & & & & & -0.254 \\
\hline Constant & $\begin{array}{c}37.224 \\
(8.79)^{\star * *}\end{array}$ & $\begin{array}{c}48.574 \\
(7.21)^{\star * *}\end{array}$ & $\begin{array}{c}28.799 \\
(6.25)^{\star * *}\end{array}$ & $\begin{array}{c}37.068 \\
(6.68)^{\star * \star}\end{array}$ & $\begin{array}{c}(0.25) \\
37.289 \\
(8.72)^{\star * *}\end{array}$ \\
\hline Observations & 477 & 243 & 234 & 477 & 477 \\
\hline R-squared & 0.53 & 0.27 & 0.24 & 0.68 & 0.53 \\
\hline
\end{tabular}

Table 6, finally, presents our estimation results for Foreign credit. The table displays a similar picture to that for local currency lending rates. Foreign currency lending rates are positively related to international interest rates, but point estimates of .5 and below again indicate weak levels of competition. Moreover, the estimates for USD rate in table 6 are of much weaker precision than our estimates for market rates in the previous tables. Again we find a significant and negative sign of Foreign bank, showing that foreign controlled banks charge substantially lower lending rates. This again suggests that lower finding costs for foreign banks, due to increased trustworthiness, have also led to lower lending rates. Also reflecting our results in table 5, we find that the bank-level explanatory variables Substandard Credit, Capital / Loans and Foreign Funds / Assets are not significantly correlated with banks' lending rates. We find a positive and significant coefficient of the interaction term 
Concentration*USD rate, in column (5). This result contradicts our prediction that more concentration in the credit market should reduce the reaction of lending rates to market rates. The finding thus suggests that recent reduction in concentration in the foreign currency lending market by no means implies that this market has become more competitive.

\section{Table 6. Foreign currency credit}

The table reports OLS estimates for interest rates on new loans in foreign currency using quarterly data for 1998-2005. See Appendix B for detailed definitions and sources of all variables. Each regression controls for the average maturity of new deposits. Robust t-statistics are reported in parenthesis based on standard errors which are adjusted for cluster effects at the bank level. One star denotes significant at $10 \%$ level; two stars significant at $5 \%$ level; three stars significant at $1 \%$ level.

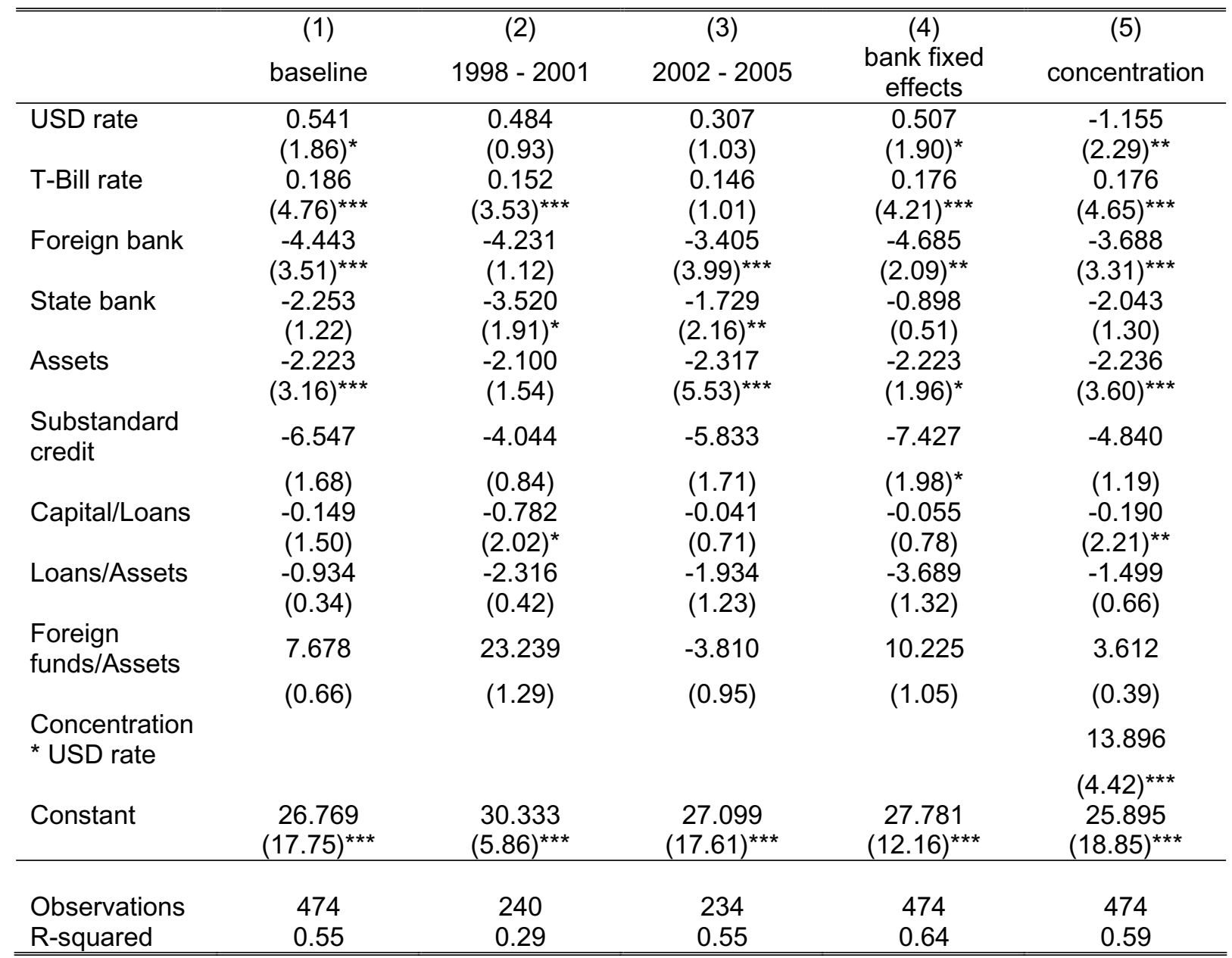

In all specifications of table 6 we include the domestic T-Bill rate as an explanatory variable of foreign currency lending rates. The domestic market rate is hereby used as an indicator of domestic macroeconomic conditions. We predict that foreign currency lending rates will be positively related to domestic macroeconomic instability, and thus to the T-Bill rate. The reason for this is that if some borrowers of foreign currency only have income in 
local currency, the credit risk on foreign currency loans depends on the stability of the local currency. If banks think that some borrowers of foreign currency loans are unhedged, they will price this "currency induced" credit risk into their lending rates. Interestingly, our results do show a positive and highly significant relationship between the domestic T-Bill rate and foreign currency lending rates. This finding confirms our conjecture that recent domestic macroeconomic stabilization may have affected credit risk, and thus lending rates on foreign currency credit.

\section{Conclusions}

We examine the impact of banking sector reform on interest rates in Kyrgyzstan over the period 1998-2005. By relating bank-level interest rates to domestic and foreign market rates, as well as bank-level indicators of intermediation costs, credit risk, capital costs and ownership we can disentangle the impact of banking sector reform from that of the decline in domestic interest rates, due to macroeconomic stabilization.

Our results suggest that increased confidence in the banking sector has contributed significantly to reducing banks' interest rates. In contrast, our results suggest that lower intermediation costs and liquidity requirements are not mirrored in higher remuneration of depositors. Moreover, lower bank-level credit risk, intermediation costs and capital costs have not significantly affected lending rates. Our results suggest that the liberalization of the Kyrgyz financial sector has been beneficial to depositors and borrowers. The presence of foreign controlled banks seems to have boosted confidence in the banking sector, and as a consequence has reduced deposit rates. Moreover, foreign banks charge significantly lower lending rates than domestic banks. Finally, our results suggest that the level of competition in the Kyrgyz banking sector is low, and that despite bank restructuring competition has not increased. As a consequence, banks interest rates do not fully reflect lower market rates, which have been brought abut by macroeconomic stabilization. 


\section{References}

Berglof E. and P. Bolton (2002): "The Great Divide and Beyond: Financial Architecture in Transition", Journal of Economic Perspectives, 16 (1), 77-100.

Bonin J.P., I. Hasan, and P. Wachtel (2005): "Bank Performance, Efficiency and Ownership in Transition Countries", Journal of Banking and Finance, 29, 31-53.

Bonin J.P., and P. Wachtel (2003): "Financial sector Development in Transition Countries: Lessons from the First Decade", Financial Markets Institutions and Instruments, 12(1).

Catao L. (1998): "Intermediation in a Dual Currency Economy: Argentina in the 1990s", IMF Working Paper WP/98/90.

Clarke C., R. Cull, M. Soledad Martinez Peria, and S.M. Sanchez (2001): "Foreign Bank Entry: Experience, Implications for Developing Countries, and Agenda for Further Research, World Bank.

De Nicolo G., S. Geadah and D. Rozhkov (2003): "Financial Development in the CIS-7 Countries: Bridging the Great Divide", IMF Working Paper WP/03/205.

Freixas X., and J.-C. Rochet (1998): "Microeconomics of Banking", MIT Press, Cambridge, MA.

Fries S. and A. Taci (2002): "Banking Reform and Development in Transition Economies", EBRD Working Paper 71.

Fries S. and A. Taci (2004): “Cost Efficiency of Banks in Transition: Evidence from 289 Banks in 15 Post-Communist Countries", EBRD Working Paper 86.

Fries S., D. Neven and P. Seabright (2002): "Bank Performance in Transition Countries", William Davidson Working Paper 505.

Grigorian D.A. and V. Manole (2002): "Determinants of Commercial Bank Performance in Transition: An Application of Data Envelopment Analysis", World Bank Policy Research Working Paper 2850.

Pistor K., M. Raiser and S. Gelfer (2000): "Law and Finance in Transition Countries", Economics of Transition, 8(2), 325-368. 


\section{Appendix A. \\ Interest rates in a dual currency banking sector}

\section{The model}

All quantities are noted in local currency. We define $e$ as the local currency / foreign currency exchange rate. An asset (liability) which is held in foreign currency and has 1 unit value of local currency at the beginning of the period $(t=0)$ will be worth $\frac{e_{1}}{e_{0}}$ at the end of the period $(t=1)$. If we define $\Delta e$ as the depreciation rate of the local currency $\frac{e_{1}-e_{0}}{e_{0}}$ the end of period value of this asset can be stated as $(1+\Delta e)$.

There is a continuum of households with one unit of savings each. Households choose whether to store their savings in cash or a bank account. Cash savings can be held in both local and foreign currency currency. Bank deposits can also be made in either foreign currency at interest rate $i_{D *}$ or local currency at interest rate $i_{D} \cdot{ }^{1}$ For simplicity we assume that households are risk-neutral and have identical beliefs concerning the expected depreciation of local currency $\Delta e$. As a consequence an equilibrium where savings are placed in both currencies can only exist if the following condition holds: ${ }^{2}$

$$
\text { [1] } i_{D}=i_{D *}+\Delta e
$$

Households are heterogenous regarding their confidence in the banking system. We define $\gamma_{h}$ as the expected loss of deposits by household $h$ due to the risk of a bank going bankrupt. A household $h$ will then only make bank deposits if $\max \left(i_{D}, i_{D *}+\Delta e\right) \geq \gamma_{h}$. Hereby the allocation of deposits to local currency and foreign currency is arbitrary if condition [1] holds. In the following we consider only equilibria in which condition [1] holds. The supply of aggregate supply of local currency deposits $D$ and foreign currency deposits $D^{*}$ is then given by:

$$
[2] D+D^{*}=f\left(i_{D}\right), \frac{\partial f}{\partial i_{D}}>0
$$

There is a continuum firms, which require one unit of credit each to make an investment. Some firms have projects which requires investment in local currency and some have projects which require investment in foreign currency. We assume that firms can only receive loans in the currency which they need for their investments. Moreover, we assume that the return on projects are heterogenous. Given lending rates $i_{L}$ for local currency credit and $i_{L^{*}}$ for foreign currency credit, the demand for local currency credit credit $L$ and foreign currency credit $L^{*}$ are then:

$$
\begin{aligned}
& {[3 a] L=g\left(i_{L}\right), \frac{\partial L}{\partial i_{L}}<0} \\
& {[3 b] L^{*}=g^{*}\left(i_{L^{*}}\right), \frac{\partial g^{*}}{\partial i_{L^{*}}}<0}
\end{aligned}
$$

\footnotetext{
${ }^{1}$ We assume, as is the case in Kyrgyzstan, that households can freely choose between making deposits in local or foreign currency. This assumption may not hold in other low-income countries where bank charges or minimum balances may be substantially higher for foreign currency deposit accounts.

${ }^{2}$ For simplicity we ignore in the following the 2 nd order interaction effect $i_{D} \Delta e$.
} 
There are $j$ identical banks in the market. All banks mobilize deposits and invest their loanable funds in either local currency government treasury bills (T-bills), local currency loans, foreign currency accounts with foreign banks (so called "nostro accounts"), or foreign currency loans. The activities of banks take place as follows:

1. In each period each bank observes the interest rate on local currency T-bills $i_{T B}$ and foreign currency "nostro" accounts $i_{N^{*}}$. Both interest rates are taken as exogenous.

2. Each bank $b$ simultaneously chooses a volume of local currency deposits $D_{b}$ and foreign currency deposits $D_{b}^{*}$ to mobilize, incurring an identical cost of $c_{D}$ per unit mobilized.

3. Based on its mobilized deposits each bank submits liquidity reserves to the regulatory authorities: $R_{b}=r\left(D_{b}+D_{b}^{*}\right)$. We define $r$ as the liquidity ratio and assume (for simplicity) that these reserves bear no interest.

4. Each bank chooses how to allocate its loanable funds. Due to currency exposure restrictions local currency loanable funds $(1-r) D_{b}$ can only be allocated to T-bills $L_{T B}$, or local currency loans $L_{b}$. Likewise, foreign currency funds $(1-r) D_{b}^{*}$ can only be allocated to nostro accounts $L_{N^{*}}$ or foreign currency loans $L_{b}^{*}$. All lending decisions are made simultaneously. Investments in T-bills or nostro accounts involve no administrative costs and are not subject to prudential capital requirements. The underwriting and monitoring of loans incur a per unit cost of $c_{L}$ for local currency loans and $c_{L^{*}}$ for foreign currency loans. Moreover, for each unit of credit provided to the private sector a bank must also raise $k \in[0,1)$ units of capital at an opportunity cost of 1 per unit. We assume that investments in nostro accounts are risk free, while investments in domestic T-bills are subject to a default probability of $\alpha_{T B} \in(0,1)$. Local currency loans are subject to an (independent) default probability of $\alpha_{L} \in(0,1)$, while foreign currency loans are subject to an (independent) default probability of $\alpha_{L^{*}} \in(0,1)$.

5. Non-performing loans are lost completely for the bank and also yield no interest income. Performing investments are repaid, including an interest rate $i_{L}$ or $i_{L^{*}}$ respectively.

6. Banks repay all deposits including interest payments $i_{D}, i_{D^{*} \cdot}{ }^{3}$

The expected profit of each bank $b$ is given by :

$$
\begin{aligned}
\pi_{b}= & {\left[\left(1-\alpha_{L}\right)\left(1+i_{L}\right)-\left(1+c_{L}+k\right)\right] L_{b} } \\
& +\left[\left(1-\alpha_{L^{*}}\right)\left(1+i_{L^{*}}\right)(1+\Delta e)-\left(1+c_{L^{*}}+k\right)\right] L_{b}^{*} \\
& -\left[i_{D}+c_{D}\right] D_{b}-\left[\left(1+i_{D^{*}}\right)(1+\Delta e)-1+c_{D}\right] D_{b}^{*} \\
& +\left[\left(1-\alpha_{T B}\right)\left(1+i_{T B}\right)-1\right]\left[[1-r] D_{b}-L_{b}\right] \\
& +\left(\left(1+i_{N^{*}}\right)(1+\Delta e)-1\right)\left[[1-r] D_{b}^{*}-L_{b}^{*}\right]
\end{aligned}
$$

Ignoring the interaction effects of repayment probabilities, interest and depreciation $\left.\left(\alpha_{L} i_{L}, \alpha_{L^{*}} i_{L^{*}}, \alpha_{T B} i_{T B}, \alpha^{*} \Delta e, i_{L^{*}} \Delta e, i_{D^{*}} \Delta e\right)\right)$ this can be simplified to:

\footnotetext{
${ }^{3}$ For simplicity we assume that bank owners have sufficient wealth to cover any losses which might be incurred by non-performing loans, and thus that they are fully liable for deposits.
} 


$$
\begin{aligned}
\pi_{b} \simeq & {\left[i_{L}-\alpha_{L}-c_{L}-k\right] L_{b} } \\
& +\left[i_{L^{*}}+\Delta e-\alpha_{L^{*}}-c_{L^{*}}-k\right] L_{b}^{*} \\
& -\left[i_{D}+c_{D}\right] D_{b}-\left[i_{D^{*}}+c_{D}+\Delta e\right] D_{b}^{*} \\
& +\left(i_{T B}-\alpha_{T B}\right)\left[[1-r] D_{b}-L_{b}\right] \\
& +\left(i_{N^{*}}+\Delta e\right)\left[[1-r] D_{b}^{*}-L_{b}^{*}\right]
\end{aligned}
$$

where $(i)$ is the expected income from domestic currency loans $L_{b},(i i)$ is the expected income from foreign currency loans $L_{b}^{*} ;(i i i)$ is the expected expenses for deposits $D_{b}, D_{b}^{*},(i v)$ is the expected income from local currency T-Bill investments, and $(v)$ is the income from foreign currency nostro accounts.

Due to the separability of intermediation costs we can examine bank behavior in two steps. We first consider the optimal allocation of a given stock of local currency and foreign currency loanable funds. We then derive the optimal amount of funds to be mobilized by each bank from the deposit market.

\section{Asset choice}

Consider a bank with local currency loanable funds $[1-r] D_{b}$ and foreign currency loanable funds $[1-r] D_{b}^{*}$. Due to currency restrictions these funds must be invested in assets of the same denomination. From [5] we see that income from buying assets with local currency funds is given by:

$$
[6 a] \pi_{b}^{L}=\left[i_{L}-\alpha_{L}-c_{L}-k\right] L_{b}+\left(i_{T B}-\alpha_{T B}\right)\left[[1-r] D_{b}-L_{b}\right]
$$

and the income from buying assets with foreign currency funds is given by:

$$
[6 b] \pi_{b}^{L^{*}}=\left[i_{L^{*}}+\Delta e-\alpha_{L^{*}}-c_{L^{*}}-k\right] L_{b}^{*}+\left(i_{N^{*}}+\Delta e\right)\left[[1-r] D_{b}^{*}-L_{b}^{*}\right]
$$

The first order conditions for maximization of $[6 a, 6 b]$, give us:

$$
\begin{aligned}
& i_{L}+\frac{\partial i_{L}}{\partial L} L_{b}-\alpha_{L}-c_{L}-k=i_{T B}-\alpha_{T B} \\
& i_{L^{*}}+\frac{\partial i_{L^{*}}}{\partial L^{*}} L_{b}^{*}-\alpha_{L^{*}}-c_{L^{*}}-k=i_{N^{*}}
\end{aligned}
$$

Let us define $\eta_{L}$ and $\eta_{L^{*}}$ as the elasticity of local currency and foreign currency credit demand (in absolute values). Given that in a symmetrical equilibrium $L_{b}=\frac{L}{j}, L_{b}^{*}=\frac{L^{*}}{j}$ ,we yield the following equilibrium lending rates:

$$
\begin{aligned}
& {[7 a] i_{L}=\left[i_{T B}+\left(\alpha_{L}-\alpha_{T B}\right)+c_{L}+k\right] \phi_{L}, \text { where } \phi_{L}=\left(\frac{j \eta_{L}}{j \eta_{L}-1}\right)} \\
& {[7 b] i_{L^{*}}=\left[i_{N^{*}}+\alpha_{L^{*}}+c_{L^{*}}+k\right] \phi_{L^{*}}, \text { where } \phi_{L^{*}}=\left(\frac{j \eta_{L^{*}}}{j \eta_{L^{*}}-1}\right)}
\end{aligned}
$$

The terms in parenthesis in $[7 a]$ and $[7 b]$ define the competitive interest rates in the local (foreign) currency credit markets. In the local currency market this is given by the opportunity cost of funds (i.e. the marginal revenue from T-bill investments) plus administrative costs of underwriting, capital costs and a risk premium on loans above the sovereign default rate. The competitive rate in the foreign currency credit market includes 
the same components except for the opportunity cost of funds which is now given by the interest rate on nostro accounts.

In both credit markets banks will charge more than the competitive interest rate if they have some degree of market power $\left(\phi_{L}, \phi_{L^{*}}>1\right)$. The smaller the number of banks and the less price elastic the demand for loans, the higher this mark-up will be.

\section{Deposit mobilization}

Profit maximizing deposit mobilization implies that the marginal revenue from local currency assets equals marginal costs of local currency deposit taking and the marginal revenue from foreign currency assets equals marginal costs of foreign currency deposit mobilization. Given the exogenous nostro rate and (risky) T-bill rate this implies the following two conditions:

$$
\begin{aligned}
& {[8 a]\left(i_{T B}-\alpha_{T B}\right)[1-r]=i_{D}+\frac{\partial i_{D}}{\partial D} D_{b}+c_{D}} \\
& {[8 b]\left(i_{N^{*}}+\Delta e\right)[1-r]=i_{D^{*}}+\frac{\partial i_{D^{*}}}{\partial D^{*}} D_{b}^{*}+c_{D}+\Delta e}
\end{aligned}
$$

As stated above we focus our attention on interior solutions, in which both local currency and foreign currency deposits are mobilized. This implies that households are indifferent between local currency and foreign currency deposit making, in which case condition [1] implies $i_{D}=i_{D *}+\Delta e$ and therefore also $\frac{\partial i_{D^{*}}}{\partial D^{*}}=\frac{\partial i_{D}}{\partial D}$. The conditions $[8 a]$ and $[8 b]$ can therefore be rewritten as:

$$
\begin{aligned}
& {[9 a]\left(i_{T B}-\alpha_{T B}\right)[1-r]-c_{D}=i_{D}+\frac{\partial i_{D}}{\partial D} D_{b}} \\
& {[9 b]\left(i_{N^{*}}+\Delta e\right)[1-r]-c_{D}=i_{D}+\frac{\partial i_{D}}{\partial D} D_{b}}
\end{aligned}
$$

Conditions $9 \mathrm{a}$ and $9 \mathrm{~b}$ allow us to deduct equilibrium conditions for the local currency deposit rate in relation to both the local currency T-bill rate and the foreign currency nostro rate. Let us define $\eta_{D}=\frac{\partial D}{\partial i_{D}} \frac{i_{D}}{D}$ as the elasticity of total deposit supply Given that in a symmetrical equilibrium we have $D_{b}=\frac{D}{J}$ we have:

$$
i_{D}=\left[\left(i_{T B}-\alpha_{T B}\right)(1-r)-c_{D}\right] \frac{1}{\phi_{D}}=\left[\left(i_{N^{*}}+\Delta e\right)(1-r)-c_{D}\right] \frac{1}{\phi_{D}}
$$

where $\phi_{D}=\left(\frac{j \eta_{D}+1}{j \eta_{D}}\right)$. Then reinserting condition [1] and ignoring the 2 nd order interaction effect $\Delta e(1-r) \frac{1}{\phi_{D}}$ we yield:

$$
[10 a] i_{D}=\left[\left(i_{T B}-\alpha_{T B}\right)(1-r)-c_{D}\right] \frac{1}{\phi_{D}}
$$

$[10 b] i_{D *}=\left[i_{N^{*}}(1-r)-c_{D}\right] \frac{1}{\phi_{D}}$

The term in parenthesis in condition $[10 a]$ gives us the competitive interest rate for the local currency deposit market. This is equal to banks' risk adjusted earnings minus regulatory and administrative costs. Likewise, the term in parenthesis in condition $[10 b]$ gives us the competitive interest rate in the foreign currency deposit market. This is equal 
to banks' risk free earnings minus regulatory and administrative costs. Both conditions show that banks may pay less than the competitive deposit rate if they have some market power, $\phi_{D}>1$.

It is important to remember that the supply of deposits is partly determined by household confidence in the banking system $\gamma$. Note that at any interest rate $i$ the elasticity of deposit supply $\eta_{D}=\frac{\partial D}{\partial i_{D}} \frac{i_{D}}{D}$ will be lower if confidence in the banking system $\gamma$ is higher (because $D$ is higher). As a consequence more confidence in the banking system will allow banks to pay less for deposits.

\section{Closing the model}

We have assumed throughout that banks take the local currency T-bill rate $i_{T B}$ and the foreign currency "nostro" rate $i_{T B}$ as given. However, given the integrated deposit market in our model an internal solution in which both foreign currency and local currency deposits are mobilized implies also an equalization of marginal returns in the local currency and foreign currency asset markets. Banks will only mobilize both type of deposits in equilibrium if their marginal revenues (adjusting for different mobilization costs) are equal. From condition [9] we see that this implies $\left(i_{T B}-\alpha_{T B}\right)(1-r)-c_{D}=$ $\left(i_{N^{*}}+\Delta e\right)(1-r)-c_{D}$

or

[11] $i_{T B}=i_{N^{*}}+\alpha_{T B}+\Delta e$

Condition [11] shows that in an internal equilibrium the interest rate differential between local currency T-bills and (risk-free) foreign currency must compensate exactly for sovereign risk of the domestic government and for currency risk of the local currency. 


\section{Appendix B. Definition and sources of variables}

\begin{tabular}{|c|c|c|}
\hline Variable Name & Description & Source \\
\hline Som deposits & $\begin{array}{l}\text { Interest rate (in \%) on new deposits in } \\
\text { Kyrgyz Som per quarter. }\end{array}$ & $\begin{array}{l}\text { National Bank of the } \\
\text { Kyrgyz Republic (NBKR) }\end{array}$ \\
\hline Foreign deposits & $\begin{array}{l}\text { Interest rate (in \%) on new deposits in } \\
\text { foreign currency per quarter. }\end{array}$ & NBKR \\
\hline Som credit & $\begin{array}{l}\text { Interest rate (in \%) on new loans in Kyrgyz } \\
\text { Som per quarter. }\end{array}$ & NBKR \\
\hline Foreign credit & $\begin{array}{l}\text { Interest rate (in \%) on new loans in foreign } \\
\text { currency per quarter. }\end{array}$ & NBKR \\
\hline T-Bill rate & $\begin{array}{l}\text { Average interest rate on newly issued 3- } \\
\text { month treasury bills of the Kyrgyz } \\
\text { government by quarter. }\end{array}$ & NBKR \\
\hline USD rate & $\begin{array}{l}\text { Average euro market interest rate on } 3 \\
\text { month US dollar bonds by quarter. }\end{array}$ & $\begin{array}{l}\text { Bank for International } \\
\text { Settlements. }\end{array}$ \\
\hline Foreign bank & $\begin{array}{l}\text { Bank with at least } 51 \% \text { foreign ownership } \\
\text { (yes/no). }\end{array}$ & NBKR \\
\hline State bank & $\begin{array}{l}\text { Bank with at least } 51 \% \text { state ownership } \\
\text { (yes/no). }\end{array}$ & NBKR \\
\hline Assets & $\begin{array}{l}\text { Log of bank assets } \\
\text { (mean per quarter, in million } 1998 \text { Som). }\end{array}$ & NBKR \\
\hline $\begin{array}{l}\text { Substandard } \\
\text { credit }\end{array}$ & $\begin{array}{l}\text { Ratio of substandard credit (in arrears for } \\
\text { more than } 30 \text { days) to total credit } \\
\text { outstanding (mean per quarter). }\end{array}$ & NBKR \\
\hline Capital / Loans & $\begin{array}{l}\text { Ratio of banks capital to total customer } \\
\text { loans (mean per quarter). }\end{array}$ & NBKR \\
\hline Loans / Assets & $\begin{array}{l}\text { Ratio of banks customer loans to total assets } \\
\text { (mean per quarter). }\end{array}$ & NBKR \\
\hline Liquidity reserves & $\begin{array}{l}\text { Regulatory liquidity reserve ratio of NBKR } \\
\text { adjusted for remuneration of reserves }\end{array}$ & NBKR \\
\hline & (mean per quarter for banking sector) & \\
\hline $\begin{array}{l}\text { Foreign funds / } \\
\text { Assets }\end{array}$ & $\begin{array}{l}\text { Ratio of loans from international financial } \\
\text { institutions or foreign banks to total assets }\end{array}$ & NBKR \\
\hline & (mean per bank and quarter). & \\
\hline \multirow[t]{2}{*}{ Concentration } & $\begin{array}{l}\text { Herfindahl-Hirschmann-Index of } \\
\text { concentration of (alternatively) Som } \\
\text { deposits, Som credit, foreign currency } \\
\text { deposits, foreign currency credit }\end{array}$ & NBKR \\
\hline & (mean per quarter) & \\
\hline
\end{tabular}




\section{Swiss National Bank Working Papers published since 2004:}

2004-1 Samuel Reynard: Financial Market Participation and the Apparent Instability of Money Demand

2004-2 Urs W. Birchler and Diana Hancock: What Does the Yield on Subordinated Bank Debt Measure?

2005-1 Hasan Bakhshi, Hashmat Khan and Barbara Rudolf: The Phillips curve under state-dependent pricing

2005-2 Andreas M. Fischer: On the Inadequacy of Newswire Reports for Empirical Research on Foreign Exchange Interventions

2006-1 Andreas M. Fischer: Measuring Income Elasticity for Swiss Money Demand: What do the Cantons say about Financial Innovation?

2006-2 Charlotte Christiansen and Angelo Ranaldo: Realized Bond-Stock Correlation: Macroeconomic Announcement Effects

2006-3 Martin Brown and Christian Zehnder: Credit Reporting, Relationship Banking, and Loan Repayment

2006-4 Hansjörg Lehmann and Michael Manz: The Exposure of Swiss Banks to Macroeconomic Shocks - an Empirical Investigation

2006-5 Katrin Assenmacher-Wesche and Stefan Gerlach: Money Growth, Output Gaps and Inflation at Low and High Frequency: Spectral Estimates for Switzerland

2006-6 Marlene Amstad and Andreas M. Fischer: Time-Varying Pass-Through from Import Prices to Consumer Prices: Evidence from an Event Study with Real-Time Data

2006-7 Samuel Reynard: Money and the Great Disinflation

2006-8 Urs W. Birchler and Matteo Facchinetti: Can bank supervisors rely on market data? A critical assessment from a Swiss perspective

2006-9 Petra Gerlach-Kristen: A Two-Pillar Phillips Curve for Switzerland

2006-10 Kevin J. Fox and Mathias Zurlinden: On Understanding Sources of Growth and Output Gaps for Switzerland

2006-11 Angelo Ranaldo: Intraday Market Dynamics Around Public Information Arrivals 
2007-1 Andreas M. Fischer, Gulzina Isakova and Ulan Termechikov: Do FX traders in Bishkek have similar perceptions to their London colleagues? Survey evidence of market practitioners' views

2007-2 Ibrahim Chowdhury and Andreas Schabert: Federal Reserve Policy viewed through a Money Supply Lens

2007-3 Angelo Ranaldo: Segmentation and Time-of-Day Patterns in Foreign Exchange Markets

2007-4 Jürg M. Blum: Why ‘Basel II’ May Need a Leverage Ratio Restriction

2007-5 Samuel Reynard: Maintaining Low Inflation: Money, Interest Rates, and Policy Stance

2007-6 Rina Rosenblatt-Wisch: Loss Aversion in Aggregate Macroeconomic Time Series

2007-7 Martin Brown, Maria Rueda Maurer, Tamara Pak and Nurlanbek Tynaev: Banking Sector Reform and Interest Rates in Transition Economies: Bank-Level Evidence from Kyrgyzstan 
Swiss National Bank Working Papers are also available at www.snb.ch, section Publications/Research Subscriptions or individual issues can be ordered at Swiss National Bank, Fraumünsterstrasse 8, CH-8022 Zurich, fax+41 4463181 14, E-mail library@snb.ch 